\title{
Economics of Sugarcane and Banana Cultivation under Drip Irrigation System: A Case Study of Northern Maharashtra
}

\author{
Subrata Gorain", D.R. Singh, Pramod Kumar, P. Venkatesh and G.K. Jha
}

Division of Agricultural Economics, ICAR-Indian Agricultural Research Institute, New Delhi, India

"Corresponding author: sgorain464@gmail.com (ORCID ID: 0000-0002-3163-2938)

Received: 23-12-2019

Revised: $20-04-2020$

Accepted: 26-05-2020

\begin{abstract}
Efficient development with proper management of the scarce water resources is the key determinants for achieving food security not only for India, but for the entire world. Drip method of irrigation act as the facilitating factors in achieving water saving in irrigation, better quality products, increased water use efficiency, decreased tillage requirement, increased yield of the crop with higher fertilizer use efficiency and investment in drip technologies are also cost effective, with short payback periods. This paper has analyzed and assessed the costs and returns associated with adoption of drip irrigation system under drip irrigation system. The result reveals that cropping intensity is highest among marginal farmers $(183.7 \%)$ followed by small (164\%) and others (116.7\%) with an overall cropping intensity of 127.9 per cent. The average gross cropped area was high for large farmers ( $5.56 \mathrm{ha}$ ) followed by small (2.76 ha) and marginal holdings (1.43 ha) as per the expectation. Cropping intensity of non-drip farmers was found to be higher than drip farmers (145\%). For both the crops, water consumption was higher in flooding than in drip and yield realization was more in drip method of irrigation. Water consumption in sugarcane was $2339 \mathrm{~m}^{3} /$ ha under drip and $3780 \mathrm{~m}^{3} /$ ha under flood irrigation. On the other hand, yield realization was $1186 \mathrm{q} / \mathrm{ha}$ under drip and only $811 \mathrm{q} / \mathrm{ha}$ under flood irrigation. Banana crop also consumed less water and produced more yield under drip irrigation over flood irrigation. Adoption of drip saved 26.43 per cent of water used under flood irrigation and increased yield by 46.3 per cent in sugarcane. Similarly, in banana cultivation, 46.4 per cent of water was saved and yield was increased by 16.75 per cent due to use of drip irrigation.

\section{Highlights}

( Drip irrigation received considerable attention to the policy makers for its significant contribution towards enhanced agricultural production, resource saving as well as environmentally sustainable.

(0 Use of drip irrigation technology saves water in sugarcane and banana and hence increases the water productivity.
\end{abstract}

Keywords: Drip irrigation, cropping intensity, water productivity

In India, demand of water for all the major sectors is growing spontaneously and demand management mechanism becomes the major key strategy to manage scarce resources of water. United Nation reported that with more than 1.3 billion population in 2017, India will be emerging as most populous country by 2024 in the world (UN Revised Population Projections 2017). Since, in India, the foremost water consuming sector is agriculture (78\% of fresh water resources), for sustainable management of water resources, the major concern would be the demand management mechanism in water scarce as well as water stressed regions (Kumar 2008). One of the major mechanisms for demand management is adoption of micro irrigation like drip and sprinkler methods of irrigation. In response, the government of India, in conjunction with state governments, has provided capital-cost

How to cite this article: Gorain, S., Singh, D.R., Kumar, P., Venkatesh, P. and Jha, G.K. (2020). Economics of sugarcane and banana cultivation under drip irrigation system: A case study of Northern Maharashtra. Economic Affairs, 65(2): 151-159.

Source of Support: None; Conflict of Interest: None 
subsidies, ranging over time from 30 per cent to 90 per cent of purchase costs, for potential drip users (Narayanamoorthy, 2008). Drip method of irrigation has immense potential to enhance the productivity of several crops with a reduction in the cost of cultivation. The reason is drip system of irrigation increased benefits through well sponsored central as well as state subsidy schemes. In many corner of India, uncontrolled withdrawal of the groundwater for crop production, supported by subsidization of electricity in farm sector, leads to rapid declines in ground water level (Kumar, 2011). As agriculture sector in India consumes 80 per cent of the total fresh water resources; central and state governments is often promoting microirrigation as a means to tackle the crisis of ground water resources. India faces recurring droughts in the consecutive years 2012, 2015 and 2016; the micro irrigation is becoming a policy priority. New demand management technologies for water saving such as drip have been introduced in Maharashtra aimed to improve the water use efficiency backed by subsidy programmes. New demand management technologies for water saving such as drip have been introduced in Maharashtra aimed to improve the water use efficiency backed by subsidy programmes. With agricultural intensification and expansion, the demand for water for irrigation purpose has been increasing. This needs efficient management of water resources and micro irrigation methods emerged as one of the effective water-saving technological intervention. Evidences show that in India 86.27 lakh ha area is under micro-irrigation in 2016. Out of which Maharashtra contributes 15.18 per cent (70 per cent drip and 30 per cent sprinkler) area under micro-irrigation (Ministry of Agriculture \& Farmers Welfare, GOI, 2016). Though presently Maharashtra ranked second in area under drip method of irrigation in India, only few studies have attempted to find the costs and returns of banana and sugarcane cultivation under drip irrigation. Hence, the present study has concentrated on the economics of sugarcane and banana cultivation under drip irrigation system along with its water productivity and profitability.

\section{MATERIALS AND METHODS}

The study is based upon both primary as well as secondary information. Secondary data on micro and drip irrigation in Maharashtra state and India were collected. Farm size-wise beneficiary's farmers for drip irrigation in Maharashtra were collected for selection of districts for primary data collection. Secondary data were collected from various governmental sources like Office of the Commissioner of Agriculture, Pune, Maharashtra, Department of agriculture Nashik and Jalgaon, Ministry of Agriculture \& Farmers Welfare, Government of India.

A structured interview schedule was developed to collect primary data from the selected farmers. The data was collected by personal interview method. Data was collected regarding basic information about the farmers, adoption status of drip irrigation system, farmer specific variables, institutional variable, credit availability, source of irrigation, constraints in adoption of drip irrigation, perception on adoption of drip irrigation, forced investment on non-functioning well, ground water table information, employment generation due to adoption of drip irrigation, water market information, information on cost of cultivation etc.

\section{Estimation of water productivity}

To estimate the water productivity of drip irrigation technology, tabular analysis was used. The profitability of drip irrigation technology of sugarcane and banana was estimated by employing various farm management cost and return concepts.

Productivity is a measure of system performance expressed as a ratio of output to input. For agricultural systems, Water Productivity (WP) in terms of yield $\left(\mathrm{q} / \mathrm{m}^{3}\right)$ or in terms of value of output $\left(₹ / \mathrm{m}^{3}\right)$ is a measure of output of a given system in relation to the water it consumes.

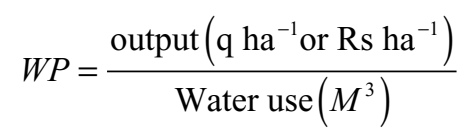

\section{Farm business analysis}

In order to assess the profitability of selected sugarcane and banana crops under drip and flood method of irrigation, various costs and return concepts were used.

\section{Cost concepts}

Various costs such as Costs $\mathrm{A}_{1}$ and $\mathrm{A}_{2^{\prime}}$ Costs $\mathrm{B}_{1}$ and 
$B_{2}$ and Costs $C_{1}, C_{2}$ and $C_{3}$ were estimated. The details of these cost concepts are given as:

- Cost $A_{1}$ : Wages of hired labour + imputed value of owned and hired bullock labour + charges of hired machinery + Imputed value of owned machinery + market rate of seed, fertilizer + market value of pesticides and other chemicals + Irrigation Charges + Land revenue + Depreciation on farm building and machinery + interest on working capital + miscellaneous expenses

- $\operatorname{Cost} A_{2}:$ Cost $A_{1}+$ rent paid on leased on land

- Cost $B_{1}$ : Cost $A_{1}+$ interest on owned capital excluding value of land

- Cost $B_{2}$ : Cost $B_{1}+$ rental value of owned land + rent paid for leased in land

- Cost $C_{1}$ : Cost $B_{1}+$ imputed value of family labour

- Cost $C_{2}$ : Cost $B_{2}+$ imputed value of family labour

- Cost $C_{3}$ : Cost $C_{2}+$ value of management input at $10 \%$ of .

\section{Return concepts}

The following return concepts were calculated as:

- Farm business income $=$ Gross income - Cost $A_{1}$

- Family labour income $=$ Gross income - Cost $B_{2}$

- Net income over Cost $C_{1}=$ Gross income - Cost $\mathrm{C}_{1}$

- Net income over Cost $\mathrm{C}_{2}=$ Gross income - Cost $\mathrm{C}_{2}$

- Net income over Cost $\mathrm{C}_{3}=$ Gross income - Cost $\mathrm{C}_{3}$

Gross income was calculated by adding the value of main product as well as the value of by-product of the particular crop.

\section{RESULTS AND DISCUSSION}

\section{Land use pattern}

Agriculture is the mainstay of the state Maharashtra. The economy of the state is predominantly agrarian with roughly $56 \%$ of the total geographical area under cultivation. Agriculture as main occupation of the people, both food crops as well as cash crops are grown through entire the state. The major principal crops are rice, bajra, jowar, onions, wheat, cotton, pulses, sugarcane, turmeric, and several oil seeds including sunflower, groundnut, and soybean.

Table 1: Land use pattern of Maharashtra state, Jalgaon and Nashik districts

\begin{tabular}{llll}
\hline \multirow{2}{*}{ Particulars } & \multicolumn{3}{c}{ Area ('000 ha) } \\
\cline { 2 - 4 } & Maharashtra Jalgaon & Nashik \\
\hline Total geographical area & 30758 & 1164 & 1563 \\
Net sown Area & 17344 & 849.2 & 867.5 \\
Area sown more than once & 5929 & 313.6 & 127.1 \\
Gross Cropped Area & 23273 & 1163 & 994.6 \\
Forest & 5194 & 155.9 & 314.8 \\
Cultivable waste land & 886 & 6.3 & 20.1 \\
Land put to non- & 1520 & 16.2 & 42.5 \\
agricultural uses & & & \\
Permanent pasture and & 1249 & 38.7 & 22.6 \\
grazing land & & & \\
Land under miscellaneous & 249 & 2.8 & 1.9 \\
tree crops and groves & & & \\
Barren uncultivated land & 1731 & 80.4 & 171 \\
Fallow lands & 2587 & 14.4 & 14.6 \\
Net irrigated area & 3947 & 213 & 244 \\
Gross irrigated area & 4962 & 295 & 311 \\
Cropping intensity (\%) & 133 & 137 & 115 \\
\hline
\end{tabular}

Source: Commissionerate of Agriculture, GoM.

The state also has huge areas under fruit cultivation of mango, banana, grape, and orange etc. The net sown area and gross cropped area of the state is 17.3 and 23.2 million hectares respectively. Only 12.5 million hectares is under the permanent pastures reflects the vital for dairying as well as livestock husbandry in the state. The gross and net irrigated area is 4.9 and 3.9 million hectares respectively. Only $23 \%$ of the net cropped area is under irrigation which highlights the dependency on rainfall and the risks associated with variability in rainfall patterns observed off late. Area under drip irrigation is 9.24 lakh hectares. The cropping intensity of the region is $133 \%$.

\section{Socio-economic characteristics of sample farms}

The general information regarding the socioeconomic characteristics of the selected drip and non-drip farmers is presented in Table 2 and 3, respectively. Among the selected drip farmers surveyed the marginal, small and other categories farmers accounted for $13.75,35.00$ and 51.25 per cent, 
respectively. However, in case of non-drip farmers, marginal, small and other farmers constituted for about 32.5, 50, and 17.50 per cent, respectively. It was found that the majority of the drip farmers were under the category of other farmers (51.25\%) and the non-drip farmers were small and marginal $(82.5 \%)$. The average size of holding for drip farmers was considerably high (3.14 ha) when compared to non-drip farms (1.54 ha).

Table 2: Socio-economic profile of drip irrigated farms

\begin{tabular}{|c|c|c|c|c|}
\hline Particulars & Marginal & Small & Others & All \\
\hline Numbers of farm (No.) & 11 & 28 & 41 & 80 \\
\hline Sample farm (per cent) & 13.75 & 35.00 & 51.25 & 100 \\
\hline $\begin{array}{l}\text { Average size of holding } \\
\text { (ha) }\end{array}$ & 0.78 & 1.69 & 4.77 & 3.14 \\
\hline Irrigated area (per cent) & 96.67 & 99.51 & 96.03 & 96.66 \\
\hline $\begin{array}{l}\text { Area under drip (per } \\
\text { cent) }\end{array}$ & 100 & 96.61 & 82.80 & 85.99 \\
\hline $\begin{array}{l}\text { Age of head of family } \\
\text { (years) }\end{array}$ & 49.91 & 45.71 & 46.98 & 46.94 \\
\hline $\begin{array}{l}\text { Farming experience } \\
\text { (years) }\end{array}$ & 19.8 & 17.4 & 20.50 & 19.23 \\
\hline $\begin{array}{l}\text { Experience in drip } \\
\text { irrigation (years) }\end{array}$ & 7.50 & 7.86 & 8.26 & 7.87 \\
\hline $\begin{array}{l}\text { Only agriculture as an } \\
\text { occupation }(\%)\end{array}$ & 95.50 & 88.20 & 79.60 & 87.76 \\
\hline \multicolumn{5}{|c|}{ Education level (per cent) } \\
\hline (a) Upto Primary & 27.01 & 24.10 & 19.40 & 23.50 \\
\hline (b) Secondary & 36.75 & 28.80 & 34.20 & 33.24 \\
\hline (c) Higher Secondary & 19.84 & 27.50 & 21.55 & 22.95 \\
\hline (d) Under graduate & 16.40 & 19.60 & 22.85 & 19.61 \\
\hline
\end{tabular}

The farmers who were solely dependent on agriculture was observed to be high in non-drip farmers $(96.70 \%)$ compared to the drip farmers $(87.76 \%)$. Nearly, one-fourth of the drip farmers were found to be poorly educated i.e., up to primary, whereas a higher proportion (42\%) of nondrip farmers were poorly educated.

Table 3: Socio-economic profile of non-drip irrigated farms

\begin{tabular}{lllll}
\hline Particulars & Marginal & Small & Others & Overall \\
\hline Numbers of farm (No.) & 13 & 20 & 7 & 40 \\
$\begin{array}{l}\text { Sample farm (per cent) } \\
\text { Average size of }\end{array}$ & 0.65 & 1.57 & 3.09 & 1.54 \\
$\begin{array}{l}\text { holding (ha) } \\
\begin{array}{l}\text { Irrigated area (per } \\
\text { cent) }\end{array}\end{array}$ & 62.11 & 66.78 & 50.62 & 66.78
\end{tabular}

Area under drip (per cent)

$\begin{array}{lllll}\text { Age of head of family } & 49.08 & 49.1 & 46.86 & 48.70\end{array}$ (years)

$\begin{array}{lllll}\text { Farming experience } & 19.85 & 21.8 & 19.26 & 20.30\end{array}$ (years)

Only agriculture as an $98.90 \quad 96.50 \quad 94.70 \quad 96.70$ occupation (\%)

Education level (per cent)

\begin{tabular}{lllll}
\hline (a) Upto Primary & 46.00 & 44.00 & 35.38 & 41.79 \\
(b) Secondary & 31.80 & 26.50 & 38.20 & 32.16 \\
(c) Higher Secondary & 18.40 & 21.10 & 19.57 & 19.69 \\
(d) Under graduate & 3.80 & 8.40 & 6.85 & 6.35 \\
\hline
\end{tabular}

\section{Cropping intensity and pattern}

Cropping intensity and pattern on the drip farms in the study area is presented in Table 4 . The result reveals that cropping intensity is highest among marginal farmers (183.7\%) followed by small (164\%) and others $(116.7 \%)$ with an overall cropping intensity of 127.9 per cent. The average gross cropped area was high for large farmers (5.56 ha) followed by small (2.76 ha) and marginal holdings (1.43 ha) as per the expectation. Sugarcane and banana, other perennial cash crops, were cultivated under drip irrigation, but their cultivation was favoured by large farmers.

Table 4: Cropping intensity and pattern on drip farms

\begin{tabular}{lllll}
\hline Particulars & Marginal & Small & Others & Overall \\
\hline $\begin{array}{l}\text { Cropping intensity } \\
\text { (\%) }\end{array}$ & 183.7 & 164.0 & 116.7 & 127.9 \\
$\begin{array}{l}\text { Gross cropped area } \\
\text { (ha) }\end{array}$ & 1.43 & 2.76 & 5.56 & 4.01 \\
\hline Area under crops (per cent) & & & \\
\hline Grapes & - & 2.58 & 27.98 & 20.49 \\
Banana & - & 14.47 & 9.30 & 10.09 \\
Sugarcane & 5.07 & 7.24 & 15.53 & 13.01 \\
Cotton & 27.81 & 27.39 & 13.68 & 17.68 \\
Onion & 8.87 & 12.92 & 6.84 & 8.41 \\
Maize (Kharif) & 17.75 & 8.01 & 9.65 & 9.65 \\
Maize (Rabi) & 6.34 & 9.30 & 6.49 & 7.16 \\
Wheat & 11.33 & 6.46 & 6.32 & 6.60 \\
Chick Pea & 7.61 & 3.10 & 1.23 & 1.99 \\
Tomato & - & 1.03 & 0.53 & 0.62 \\
Others & 12.68 & 3.88 & 1.75 & 2.80 \\
\hline
\end{tabular}

The cropping intensity and pattern of non-drip farmers is shown in Table 5. Cropping intensity of 
non-drip farmers was found to be higher than drip farmers $(145 \%)$. This was on account of cultivation of more area under seasonal crops and less area under perennial crops.

Table 5: Cropping intensity and pattern on non-drip farms

\begin{tabular}{lccll}
\hline Particulars & Marginal & Small & Others & Overall \\
\hline $\begin{array}{l}\text { Cropping intensity } \\
(\%)\end{array}$ & 164.3 & 154.1 & 124.1 & 145.0 \\
$\begin{array}{l}\text { Gross cropped area } \\
\text { (ha) }\end{array}$ & 1.06 & 2.42 & 3.83 & 2.23 \\
\hline Area under crops (per cent) & & & \\
\hline Banana & 0.00 & 0.00 & 8.96 & 2.70 \\
Sugarcane & 24.64 & 15.70 & 7.46 & 14.61 \\
Cotton & 11.59 & 31.82 & 28.36 & 27.64 \\
Onion & 27.54 & 20.25 & 8.96 & 17.98 \\
Maize (Kharif) & 15.94 & 17.36 & 20.90 & 18.20 \\
Maize (Rabi) & 0.00 & 0.00 & 5.97 & 1.80 \\
Wheat & 0.00 & 4.13 & 4.48 & 3.60 \\
Chick Pea & 2.90 & 4.96 & 2.99 & 4.04 \\
Tomato & 0.00 & 1.65 & 0.00 & 0.90 \\
Others & 17.39 & 4.13 & 11.94 & 8.54 \\
\hline
\end{tabular}

Cropping intensity was found to be highest in case non adopter as compared to drip farms. This can be attributed to the fact that the non-adopters are allocating more area under field cropsand less area under perennial crops like grapes, banana, sugarcane etc.

\section{Water consumption and productivity}

Water consumption of drip and non-drip farmers, water saving and increase in yield due to use of drip irrigation in sugarcane and banana cultivation is presented in Table 6. For both the crops, water consumption was higher in flooding than in drip and yield realization was more in drip method of irrigation. Water consumption in sugarcane was $2339 \mathrm{~m}^{3} /$ ha under drip and $3780 \mathrm{~m}^{3} /$ ha under flood irrigation. On the other hand, yield realization was 1186 q/ha under drip and only 811 q/ha under flood irrigation. Banana crop also consumed less water and produced more yield under drip irrigation over flood irrigation. Adoption of drip saved 26.43 per cent of water used under flood irrigation and increased yield by $46.3 \%$ in sugarcane. Similarly, in banana cultivation, 46.4 per cent of water was saved and yield was increased by 16.75 per cent due to use of drip irrigation.
Table 6: Water consumption and yield realization of major crops on drip and non-drip farms

\begin{tabular}{|c|c|c|c|c|c|c|}
\hline \multirow[t]{2}{*}{ Crops } & \multicolumn{2}{|c|}{$\begin{array}{c}\text { Water } \\
\text { consumption } \\
\left(\mathrm{m}^{3} / \mathrm{ha}\right)\end{array}$} & \multicolumn{2}{|c|}{$\begin{array}{l}\text { Yield } \\
\text { (q/ha) }\end{array}$} & \multirow{2}{*}{$\begin{array}{l}\text { Water } \\
\text { saving } \\
\text { on drip } \\
\text { farms } \\
(\%)\end{array}$} & \multirow{2}{*}{$\begin{array}{l}\text { Yield } \\
\text { increase } \\
\text { on drip } \\
\text { farms } \\
(\%)\end{array}$} \\
\hline & Drip & Flood & Drip & Flood & & \\
\hline Sugarcane & 2339.45 & 3179.98 & 31186 & 810.8 & 26.43 & 46.3 \\
\hline Banana & 4225.89 & 7884.70 & 702.7 & 601.9 & 46.4 & 16.75 \\
\hline
\end{tabular}

Water productivity of sugarcane and banana crops in drip and non-drip farms is presented in Table 7. Water productivity in physical quantity and in value of output was found to be more on drip farms than non-drip farms for both sugarcane and banana crops. Water productivity in terms of yield was $0.51 \mathrm{q} / \mathrm{m}^{3}$ on drip farms and $0.25 \mathrm{q} / \mathrm{m}^{3}$ on nondrip farms in sugarcane. In case of banana also, yield was more on drip farms $\left(0.17 / \mathrm{m}^{3}\right)$ than that of non-drip farms $\left(0.08 \mathrm{q} / \mathrm{m}^{3}\right)$. Drip farms had water productivity of $124.23 \mathrm{~F} / \mathrm{m}^{3}$ and farms irrigated through flooding had $62.47 ₹ / \mathrm{m}^{3}$ for sugarcane. Similarly for banana crop on drip farms had higher water productivity $\left(99.77 ₹ / \mathrm{m}^{3}\right)$ than farms practicing flooding $\left(45.8 ₹ / \mathrm{m}^{3}\right)$.

Table 7: Water productivity of major crops on drip and non-drip farms

\begin{tabular}{lllll}
\hline \multirow{2}{*}{ Crops } & \multicolumn{2}{c}{$\begin{array}{c}\text { Water productivity: } \\
\text { yield }\left(\mathbf{q} / \mathbf{m}^{3}\right)\end{array}$} & \multicolumn{2}{c}{$\begin{array}{c}\text { Water productivity: } \\
\text { value of output }\left(₹ / \mathbf{m}^{3}\right)\end{array}$} \\
\cline { 2 - 5 } & Drip & Flood & Drip & Flood \\
\hline Sugarcane & 0.51 & 0.25 & 124.23 & 62.47 \\
Banana & 0.17 & 0.08 & 99.77 & 45.80 \\
\hline
\end{tabular}

\section{Input cost in cultivation of sugarcane crop on drip farms}

Total input costs incurred in the sugarcane cultivation is computed and presented in the Table 8. The table revealed that the total input costs were ₹ 150661, ₹ 142117 , ₹ 134496 and ₹ 140572 for marginal, small, other and all category of farmers respectively. Hired labour is found to be having the highest (49.4\%) share in the total input costs incurred by the farmer. From the perusal of the table, it was observed that family labour costs, seed costs, machinery charges and total input costs decreased with increase in size of holding. On the contrary, hired labour and NPK fertilizer costs continuously increased with the size of holding. 
Table 8: Input cost in sugarcane cultivation on drip farms

\begin{tabular}{lllllllll}
\hline \multirow{2}{*}{ Particulars } & \multicolumn{3}{c}{ Input cost (₹/ ha) } & \multicolumn{5}{c}{ Share in total inputs cost (\%) } \\
\cline { 2 - 8 } & Marginal & Small & Others & All & Marginal & Small & Others & All \\
\hline Family labour & 14200 & 13480 & 12200 & 12862 & 9.43 & 9.49 & 9.07 & 9.15 \\
Hired labour & 65400 & 68280 & 70429 & 69569 & 43.41 & 48.05 & 52.36 & 49.49 \\
Machinery charges & 12480 & 10212 & 8522 & 9627 & 8.28 & 7.19 & 6.34 & 6.85 \\
Seed costs & 18772 & 17092 & 15914 & 16587 & 12.46 & 12.03 & 11.83 & 11.80 \\
Irrigation charges & 14000 & 10600 & 7714 & 9308 & 9.29 & 7.46 & 5.74 & 6.62 \\
FYM charges & 8000 & 7904 & 7226 & 7998 & 5.31 & 5.56 & 5.37 & 5.69 \\
NPK charges & 17809 & 14548 & 12491 & 14622 & 11.82 & 10.24 & 9.29 & 10.40 \\
Total inputs cost & 150661 & 142117 & 134496 & 140572 & 100 & 100 & 100 & 100 \\
\hline
\end{tabular}

\section{Farm business analysis of sugarcane} cultivation on drip farms

Farm business analysis was utilized to quantify the costs and returns in sugarcane cultivation for the drip farmers and presented in Table 9. The average yield obtained by the cultivation of sugarcane under drip irrigation was $1231 \mathrm{q} / \mathrm{h}$. Cost $\mathrm{C}_{3}$ was found to be ₹ 203869 per ha for all the category of farmers and was highest in case of marginal farmers (₹ 232936/ha). Higher Cost $C_{3}$ on the marginal farm can be attributed to the relatively higher labour and NPK use and machinery costs per ha. However, net income over cost $\mathrm{C}_{3}$ was observed to be highest for the other category of farmers (₹ 96492/ha) among all the category of farmers, on account of economies of scale.

Table 9: Costs and returns in sugarcane cultivation on drip farms (₹/ha)

\begin{tabular}{lllll}
\hline Particulars & Marginal & Small & Others & All \\
\hline Yield (q/ha) & 1280.2 & 1218.1 & 1196.3 & 1231.0 \\
Cost $\mathrm{A}_{1}$ & 155786 & 142152 & 135867 & 141730 \\
Cost $\mathrm{B}_{1}$ & 171960 & 147582 & 144029 & 149653 \\
Cost $\mathrm{B}_{2}$ & 197560 & 172032 & 166529 & 172474 \\
CostC $_{1}$ & 186160 & 161062 & 156229 & 162514 \\
CostC & 211760 & 185512 & 178729 & 185335 \\
CostC & 232936 & 204063 & 196601 & 203869 \\
Gross Returns & 313649 & 298435 & 293094 & 301592 \\
$\begin{array}{l}\text { Farm Business } \\
\text { Income }\end{array}$ & 157863 & 156282 & 157227 & 159862 \\
$\begin{array}{l}\text { Family Labour } \\
\text { Income }\end{array}$ & 116089 & 126402 & 126565 & 129118 \\
$\begin{array}{l}\text { Net Income over } \\
\text { Cost } C_{1}\end{array}$ & 127489 & 137372 & 136865 & 139078 \\
$\begin{array}{l}\text { Net Income over } \\
\text { Cost } C_{2}\end{array}$ & 101889 & 112922 & 114365 & 116257 \\
Net Income over & 80713 & 94371 & 96492 & 97723 \\
Cost $C_{3}$ & & & & \\
\hline
\end{tabular}

Input cost in cultivation of sugarcane crop on non-drip farms

Input cost of sugarcane cultivation under non drip method of irrigation is presented in Table 10. On an average, total input costs for all the category of farmers was found to be ₹ 123845 per ha. Hired labour costs $(44.62 \%)$ was resulted to be highest contributor among all the input costs incurred to the farmer. Seed value and NPK fertilizer charges accounted for 17.88 and 13.14 per cent of the input costs respectively. FYM costs and the machinery charges were contributing least share with the percentage of 2.35 and 5.15 per cent, respectively. Marginal farmers incurred higher input costs followed by other category and small farmers in sugarcane under flood irrigation.

\section{Farm business analysis of sugarcane cultivation on non-drip farms}

Different cost and returns concepts were computed for non-drip cultivation in sugarcane and presented Table 11. Average yield levels for the non-drip farmers were $810.8 \mathrm{q} / \mathrm{ha}$ and quite lower than drip farmers. Cost $\mathrm{C}_{3^{\prime}}$ which is also called as total cost, was found to be ₹ 185423/ha. Marginal farmers incurred higher cost and also realized higher yield levels compared to small and other category of farmers. Family labour and family business incomes on all non-drip farms were observed as ₹ 73179 and ₹ 42366 per ha, respectively. Net income over cost $\mathrm{C}_{3}$ was least for marginal farmer ( $₹ 3717 / \mathrm{ha}$ ) and it increases as the farm size increases.

\section{Input cost in cultivation of banana cultivation on drip and non-farms}

The input costs in the cultivation of banana and 
Table 10: Input cost of sugarcane cultivation on non-drip farms (₹/ha)

\begin{tabular}{lcccccccc}
\hline & \multicolumn{3}{c}{ Input cost (₹/ ha) } & \multicolumn{4}{c}{ Share in total inputs cost (\%) } \\
Particulars & Marginal & Small & Others & All & Marginal & Small & Others & All \\
\hline Family labour & 16201 & 12798 & 8023 & 12275 & 12.07 & 10.53 & 6.57 & 9.91 \\
Hired labour & 50982 & 55178 & 62843 & 55260 & 37.98 & 45.42 & 51.46 & 44.62 \\
Machinery charges & 7038 & 6337 & 5848 & 6375 & 5.24 & 5.22 & 4.79 & 5.15 \\
Seed cost & 26154 & 20109 & 21817 & 22146 & 19.49 & 16.55 & 17.86 & 17.88 \\
Irrigation charges & 3699 & 2574 & 2619 & 2876 & 2.76 & 2.12 & 2.14 & 2.32 \\
FYM charges & 9358 & 9087 & 7299 & 8635 & 6.97 & 7.48 & 5.98 & 6.97 \\
NPK charges & 20793 & 15409 & 13675 & 16278 & 15.49 & 12.68 & 11.20 & 13.14 \\
Total inputs cost & 134226 & 121491 & 122124 & 123845 & 100 & 100 & 100 & 100 \\
\hline
\end{tabular}

Table 11: Costs and returns in sugarcane cultivation on non-drip farms (₹/ha)

\begin{tabular}{lllll}
\hline Particulars & Marginal & Small & Others & All \\
\hline Yield (q/ha) & 832.6 & 805.2 & 795.3 & 810.8 \\
Cost $A_{1}$ & 133286 & 123180 & 126703 & 125478 \\
Cost $B_{1}$ & 144263 & 134696 & 134189 & 135502 \\
Cost $B_{2}$ & 165863 & 155366 & 154049 & 156291 \\
Cost $C_{1}$ & 160464 & 147495 & 142211 & 147778 \\
Cost $C_{2}$ & 182064 & 168165 & 162071 & 168566 \\
Cost $C_{3}$ & 200270 & 184981 & 178279 & 185423 \\
Gross Returns & 203987 & 197274 & 194849 & 198657 \\
Farm Business Income & 70701 & 74094 & 68146 & 73179 \\
Family Labour Income & 38124 & 41908 & 40800 & 42366 \\
Net Income over Cost $C_{1}$ & 43523 & 49779 & 52637 & 50879 \\
Net Income over Cost $C_{2}$ & 21923 & 29109 & 32777 & 30090 \\
Net Income over Cost $C_{3}$ & 3717 & 12293 & 16570 & 13234 \\
\hline
\end{tabular}

their share in the total input costs for drip and nondrip farms is presented in Table 12. The average input costs on drip and non-drip farms were ₹ 90901 and ₹ 96984 per ha, respectively. From the perusal of the table, it was found that seed costs was the highest contributor to the total input costs for both the drip (42\%) and non-drip (39.96\%) farmers.

Table 12: Input cost in Banana cultivation on drip and non-drip farms (₹/ha)

\begin{tabular}{lllll}
\hline \multirow{2}{*}{ Particulars } & \multicolumn{2}{c}{ Input cost } & \multicolumn{2}{c}{$\begin{array}{c}\text { Share in total } \\
\text { inputs cost (\%) }\end{array}$} \\
\cline { 2 - 5 } & Drip & Non-drip & Drip & Non-drip \\
\hline Family labour & 5050 & 5557 & 5.56 & 5.73 \\
Hired labour & 16325 & 18745 & 17.96 & 19.33 \\
Machinery charges & 6121 & 4162 & 6.73 & 4.29 \\
Seed cost & 38400 & 38752 & 42.24 & 39.96 \\
Irrigation charges & 8767 & 11843 & 9.64 & 12.21 \\
FYM charges & 7000 & 8132 & 7.70 & 8.38 \\
NPK charges & 14288 & 15350 & 15.72 & 15.83 \\
Total input costs & 90901 & 96984 & 100 & 100 \\
\hline
\end{tabular}

Other major costs were found to be hired labour, NPK costs and FYM costs etc. Hired labour, FYM cost and family labour charges were found to be relatively higher for non-drip farmers. Whereas, only machinery charges was higher for drip farmers in the study area. It is important to note that irrigation charges on non-drip farms were quite higher than drip farms.

\section{Farm business analysis of banana cultivation on drip and non-farms}

Farm business analysis of banana cultivation under both drip and non-drip farms is presented in Table 13. The average yield levels of the drip and non-drip farms were found to be $702.7 \mathrm{q} / \mathrm{ha}$ and $601.9 \mathrm{q} / \mathrm{ha}$, respectively. The yield levels of non-drip farms were considerably lower than the drip farms. Cost $\mathrm{A}_{1}$ was higher for non- drip farms (₹ 103093/ha) compared to drip farms (₹ 96769/ha). The returns concepts such as gross returns, farm business income, family labour income and net income over Cost $C_{3}$ was observed to be higher for the drip farms compared to non-drip farms. 
Table 13: Costs and returns in Banana cultivation on drip and non-drip farms (₹/ha)

\begin{tabular}{lll}
\hline Particulars & Drip & Non-drip \\
\hline Yield $(\mathrm{q} / \mathrm{ha})$ & 702.7 & 601.9 \\
Cost $\mathrm{A}_{1}$ & 96769 & 103093 \\
Cost $\mathrm{B}_{1}$ & 104692 & 110523 \\
Cost $\mathrm{B}_{2}$ & 128513 & 131312 \\
Cost $\mathrm{C}_{1}$ & 115316 & 121271 \\
Cost $\mathrm{C}_{2}$ & 139137 & 142060 \\
Cost $\mathrm{C}_{3}$ & 153051 & 156266 \\
Gross Returns & 421620 & 361140 \\
Farm Business Income & 319277 & 252856 \\
Family Labour Income & 287533 & 224637 \\
Net Income over Cost $\mathrm{C}_{1}$ & 306304 & 239869 \\
Net Income over Cost $\mathrm{C}_{2}$ & 282483 & 219080 \\
Net Income over Cost $\mathrm{C}_{3}$ & 268569 & 204874 \\
\hline
\end{tabular}

The average yield levels of the drip and non-drip farms were found to be $702.7 \mathrm{q} / \mathrm{ha}$ and $601.9 \mathrm{q} / \mathrm{ha}$, respectively. The yield levels of non-drip farms were considerably lower than the drip farms. Cost $\mathrm{A}_{1}$ was higher for non- drip farms ( $₹$ 103093/ha) compared to drip farms (₹ 96769/ha). The returns concepts such as gross returns, farm business income, family labour income and net income over Cost $C_{3}$ was observed to be higher for the drip farms compared to non-drip farms.

For both the water intensive crop, sugarcane yield was more in marginal farmer as compared to small and others farmers on drip and flood irrigated farms. The possible reason behind this is high resource use efficiency and management efficiency. As farm size increases the cost of family labour has decreased but the cost of hired labour has increased. Irrigation cost is another important cost, this is also higher on marginal farms. Per hectare gross return was more in banana as compared to sugarcane, indicating banana is more profitable than sugarcane because banana is the most important cash crop of the tract. The more input cost of drip farm as compared to non-drip farm in case of banana was due to more hired labour use and increase in irrigation charges. Lower input cost higher returns on drip irrigated farms reflects the higher benefit of adoption of drip irrigation system.

\section{CONCLUSIONS}

Drip irrigation received considerable attention to the policy makers for its significant contribution towards enhanced agricultural production, resource saving as well as environmentally sustainable. Cropping intensity on drip farms was lower than non-drip farms on account of cultivation of more area under more water requiring and high value perennial crops. Further, cropping intensity on marginal farms was higher than small and other farms due to cultivation of seasonal crops. Water productivity in yield and monetary terms was found to be almost double under drip irrigation as compared to flood irrigation. Water productivity is the major concern of the study and found to be quite high on drip farms than flooded farms. Farmers can decrease the input cost by adoption of drip irrigation by applying less water, irrigating more area and reduced energy cost and produce higher and quality output. Although, the cost of cultivation was high on drip irrigated farms in comparison to flood irrigated farms on account of higher input use especially labour wages and irrigation cost, the returns realization were also more and impressive on account of higher yields in sugarcane. The returns were also impressive in case of banana cultivation on drip farms than that of non-drip farms. The drip irrigation was found to be economically viable and socially acceptable also. The impressive results costs and returns justify the huge amount of subsidy burden as social cost. In nutshell, integrated and comprehensive efforts are necessary to ensure faster adoption of drip irrigation for conservation of water and energy resources, enhancing quantity and quality of agricultural productivity and improving rural livelihoods.

\section{ACKNOWLEDGEMENTS}

The paper is based on the M.Sc. thesis entitled "Socio-Economic Impact of Drip Irrigation in Northern Maharashtra" submitted to PG School, ICAR-IARI, New Delhi, by the first author under the chairmanship of the second author. The authors thank the anonymous referees for their constructive comments.

\section{REFERENCES}

Dhawan, B.D. 2000. Drip irrigation: Evaluating returns. Economic and Political Weekly, 3775-3780.

FICCI. 2016. Accelerating growth of Indian agriculture: Micro irrigation and efficient solution, strategy paper-future prospects of micro irrigation in India. Federation of Indian Chambers of Commerce and Industry and Irrigation Association of India, New Delhi. 
Kumar, D.S. 2012 Adoption of drip irrigation system in India: Some experience and evidence. The Bangladesh Development Studies, pp. 61-78.

Kumar, D.S. and Palanisami, K. 2011. Can drip irrigation technology be socially beneficial? Evidence from Southern India. Water Policy, 13(4): 571-587.

Kumar, M.D. 2008. Managing water in the face of growing scarcity, inequity and declining returns: exploring fresh approaches. In: Conference proceedings of the $7^{\text {th }}$ Annual Partners Meet, IWMI TATA Water Policy Research Program, ICRISAT, Patancheru, Hyderabad, India, 2-4 April 2008. Vol. 2.
Narayanamoorthy, A. 2008. Economics of drip irrigated cotton: a synthesis of four case studies. In: Proceedings of the $7^{\text {th }}$ Annual Partners Meet, International Water Management Institute (IWMI) TATA Water Policy Research Program, ICRISAT, 2-4.

United Nations Department of Economic and Social Affairs. 2017. Population Division World Population Prospects: The 2017 Revision. 
